\title{
PROCESOS DE SIGNIFICACIÓN Y RESIGNIFICACIÓN DE UNA CIUDAD, TEMUCO 1881-20198
}

Processos de significado e ressignificação de uma cidade, Temuco 1881-2019

Processes of signification and resignification of a city, Temuco 1881-2019

Jaime Edgardo Flores Chávez

Académico, Departamento de Ciencias Sociales e Investigador del Centro de Investigaciones Territoriales (CIT). Universidad de La Frontera. Temuco, Chile.

gmanzi@uchilefau.cl

https://orcid.org/0000-0001-6153-2922

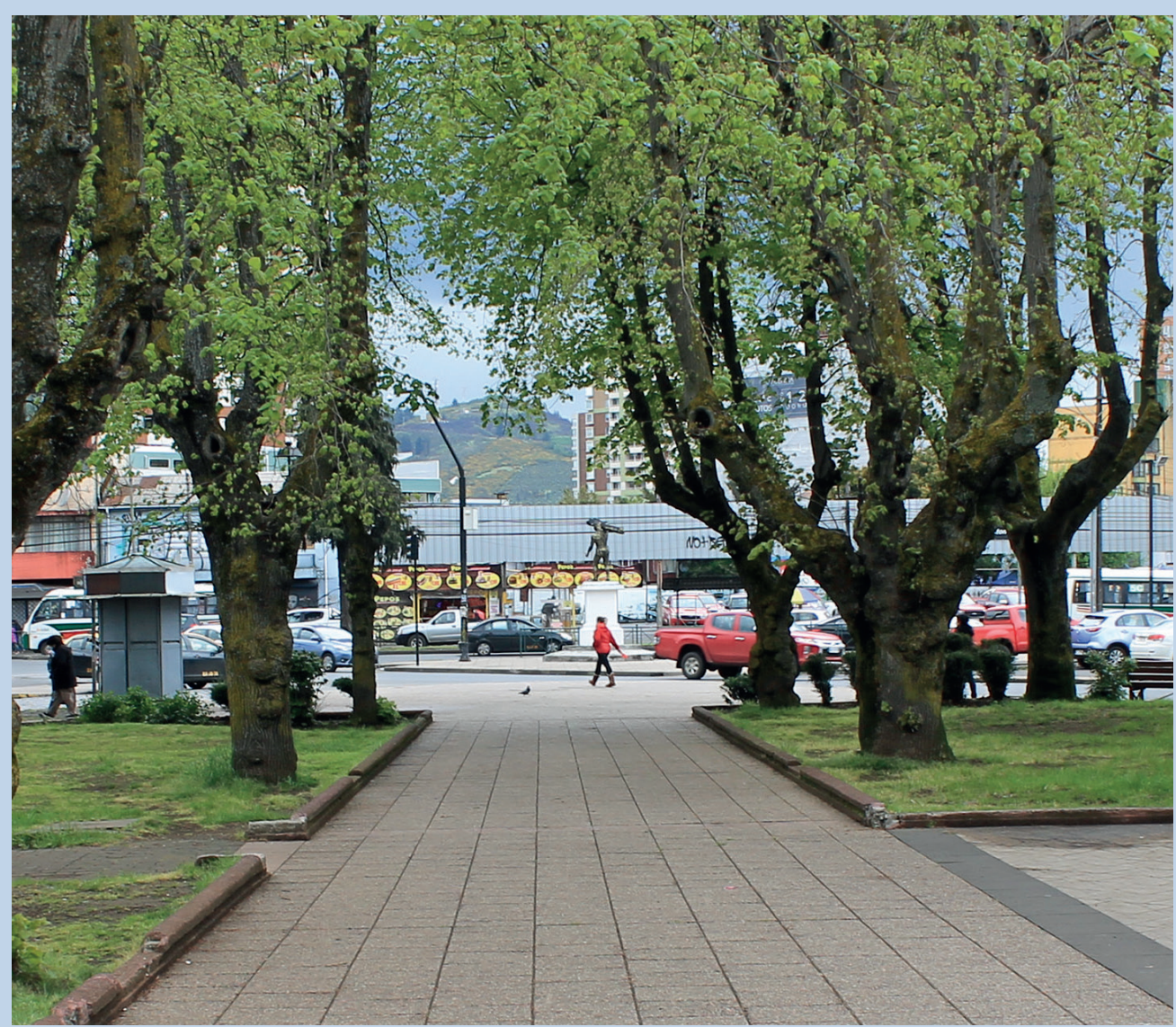

Este artículo fue financiado por la Dirección de Investigación de la Universidad de La Frontera, en el marco de los proyectos DIUFRO $n^{\circ}$ DI19-0028, n DI15-0045 y $\mathrm{n}^{\circ} \mathrm{DI} 15-0026$. 


\section{RESUMEN}

El estallido social desencadenado a partir de octubre de 2019 tuvo, entre sus expresiones más visibles, la ocupación de espacios públicos como calles, avenidas y plazas. También fue profusamente registrado el "ataque" a los monumentos que algunos asociaron a una suerte de rebelión contra la historia de Chile. Estos hechos nos conducen por los caminos de la historia, la memoria, el recuerdo y el olvido, representado en monumentos, símbolos oficiales, nombres de calles y plazas de la ciudad. También por senderos interdisciplinarios para abordar esta complejidad con metodologías y fuentes diversas. El presente artículo busca explicar lo ocurrido en Temuco, capital de la Región de la Araucanía, durante los últimos meses de 2019. Para ello se propone una aproximación investigativa desde una perspectiva de larga duración, que posibilite encontrar los elementos que fueron significando el espacio urbano, para luego explorar lo ocurrido en un tiempo corto, entre octubre y noviembre, en la lógica de los procesos de resignificación del espacio urbano.

Palabras Clave: ciudad, significación, resignificación, estallido social, Temuco

\section{RESUMO}

O levante popular desencadeado a partir de outubro de 2019 teve, entre suas expressões mais visíveis, a ocupação de espaços públicos como ruas, avenidas e praças. $O$ "ataque" aos monumentos que alguns associaram a uma espécie de rebelião contra a história do Chile também foi amplamente registrado. Esses fatos nos levam pelos caminhos da história, da memória, da lembrança e do esquecimento, representados em monumentos comemorativos, símbolos oficiais, nomes de ruas e praças instaladas na cidade. Também por caminhos interdisciplinares para abordar essa complexidade com diversas metodologias e fontes. Este artigo procura explicar o que aconteceu em Temuco, capital da região da Araucanía, durante esses meses. Para esse fim, propõe-se uma abordagem de pesquisa a partir de uma perspectiva de longo prazo que permita encontrar os elementos que foram significando o espaço urbano, para então explorar o que ocorreu em um curto tempo, entre outubro e novembro, pela lógica dos processos de ressignificação do espaço urbano.

Palavras Chave: cidade, significado, ressignificação, revolução social, Temuco

\section{ABSTRACT}

The social unrest that unfolded from October 2019 on saw, among its most visible expressions, the occupation of public spaces like streets, avenues and squares. The "attack" on the monuments that some associated with a kind of rebellion against the history of Chile was also extensively recorded. These events lead us along the paths of history, memory, remembrance and oblivion, represented in monuments, official symbols, the names of streets, squares and parks around the city, and also, along interdisciplinary paths to address this complexity using diverse methodologies and sources. This article seeks to explain what happened in Temuco, the capital of the Araucanía Region, during the last few months of 2019. For this purpose, a research approach is proposed using a long-term perspective that makes it possible to find the elements that started giving a meaning to the urban space, to then explore what occurred in a short time, between October and November, in the logic of the urban space resignification process.

Keywords: city, signification, resignification, social unrest, Temuco 


\section{INTRODUCCIÓN \\ EL CONTEXTO HISTÓRICO \\ DE LA CIUDAD EN LA \\ ARAUCANÍA}

Entendemos la ciudad como una comunidad humana y "materialidad arquitectónica" que ha sido construida por sus habitantes a lo largo de generaciones, por ende, portadoras y receptáculos de significados. En este sentido debemos asumir que las ciudades son realidades permanentemente inacabadas y constituyen "auténticos archivos de la memoria" que pueden ser leídas como un texto (Colom, 20 I 6). Para ello es necesario conocer su historia, sus formas de organización social y económica, su trama urbana y los relatos que narran cómo ha llegado a ser lo que es. La ciudad, entendida como una materialización de las ideas, los valores y los intereses a lo largo del tiempo, es evidencia de un proceso dinámico que es necesario mirar y analizar de manera amplia. (Colom, 20 I6). Sus monumentos, registros escritos y hábitos de asociación posibilitaron a la ciudad extender el alcance de las actividades humanas más allá de sus límites físicos para proyectarlas hacia el pasado y el futuro. Esta capacidad de transmitir una cultura compleja de una generación a otra, sigue siendo el "don" máximo de las ciudades (Mumford, 20I2). Por otro lado, la ciudad define "la cultura de habitar", lo que se encuentra en el centro de la tensión entre "proyecto y experiencia", y que pone en relación a quien emprende la planificación urbana con el sujeto que habita el espacio; entre aquello que los planificadores han querido que fuera y lo que las gentes han hecho de ella. La tensión entre los dos principios básicos en la constitución de los centros urbanos, por una parte la voluntad de conformar la ciudad como estructura inscrita en un lugar, y por otra, las improntas que la vida cotidiana imprime en los espacios en los que se desarrolla (Llorente, 20 I5), así, "la fundación de una ciudad es el resultado histórico de una decisión sobre el uso y la organización del espacio" (Colom, 2016), y su desarrollo, una tensión entre los "planificadores-urbanistas" y el habitar de la gente.

En la Araucanía, las ciudades llegaron con los conquistadores españoles; desde ese instante y hasta el presente, es posible identificar tres momentos. El primero, concluyó con el levantamiento mapuche iniciado en 1598 y la destrucción de las siete ciudades del Sur. En el segundo, las ciudades permanecieron en calidad de ruinas, una suerte de hito de memoria de larga duración que se rememora con el avance del Estado chileno al sur del Bío Bío, a mediados del siglo XIX. Esto marca el inicio del tercer momento, en que los proyectos militares de ocupación se prodigaban en estrategias donde los fuertes jugaban un rol fundamental para la derrota militar mapuche, al tiempo que se constituían en germen de ciudades que controlarían la población, el territorio y activarían la economía (Saavedra, 1870). Entre 1862 y I883, se refundaron y fundaron alrededor de cuarenta poblados. La resistencia mapuche fue intensa (León, 1981; Pinto, 2015). Una de las últimas expresiones de oposición armada mapuche fue el alzamiento general de |88।; entre otros fuertes atacaron Temuco. En esa oportunidad, la principal sanción fue el establecimiento del fuerte Cholchol, "en el centro mismo de sus reducciones, como una amenaza constante para siempre que abriguen el pensamiento de levantarse" (Memoria Ministerio de Guerra, 1882). Como en el pasado, la ciudad pasó a significar un espacio de castigo, la derrota militar mapuche 
impuso la consolidación de los centros urbanos como espacios de dominación y organización de una nueva territorialidad.

En 1877, los militares habían identificado "un lugar Ilamado Temuco" como punto estratégico donde ubicar un fuerte. Cuando las tropas avanzaron sobre el río Cautín se tenían estos antecedentes y, el 24 de febrero de |881, el ingeniero Teodoro Schmidt inició los trabajos topográficos, trazó el cuartel y algunas avenidas, con lo que se dio por fundado el pueblo. Más tarde, el ingeniero Fiebig completó el trabajo delineando las calles y la Plaza de Armas (La Mañana, febrero 24 de 1917). Años más tarde, 1892, el ingeniero Christian Sommermeier confeccionó el primer plano regulador de Temuco del que se tiene conocimiento [Figura I]. La construcción de la futura ciudad implicó talar árboles y cavar para sacar sus raíces; rellenar, canalizar y proyectar calles que, en un principio, fueron más bien senderos con dirección a otros fuertes (Arellano, 1931).

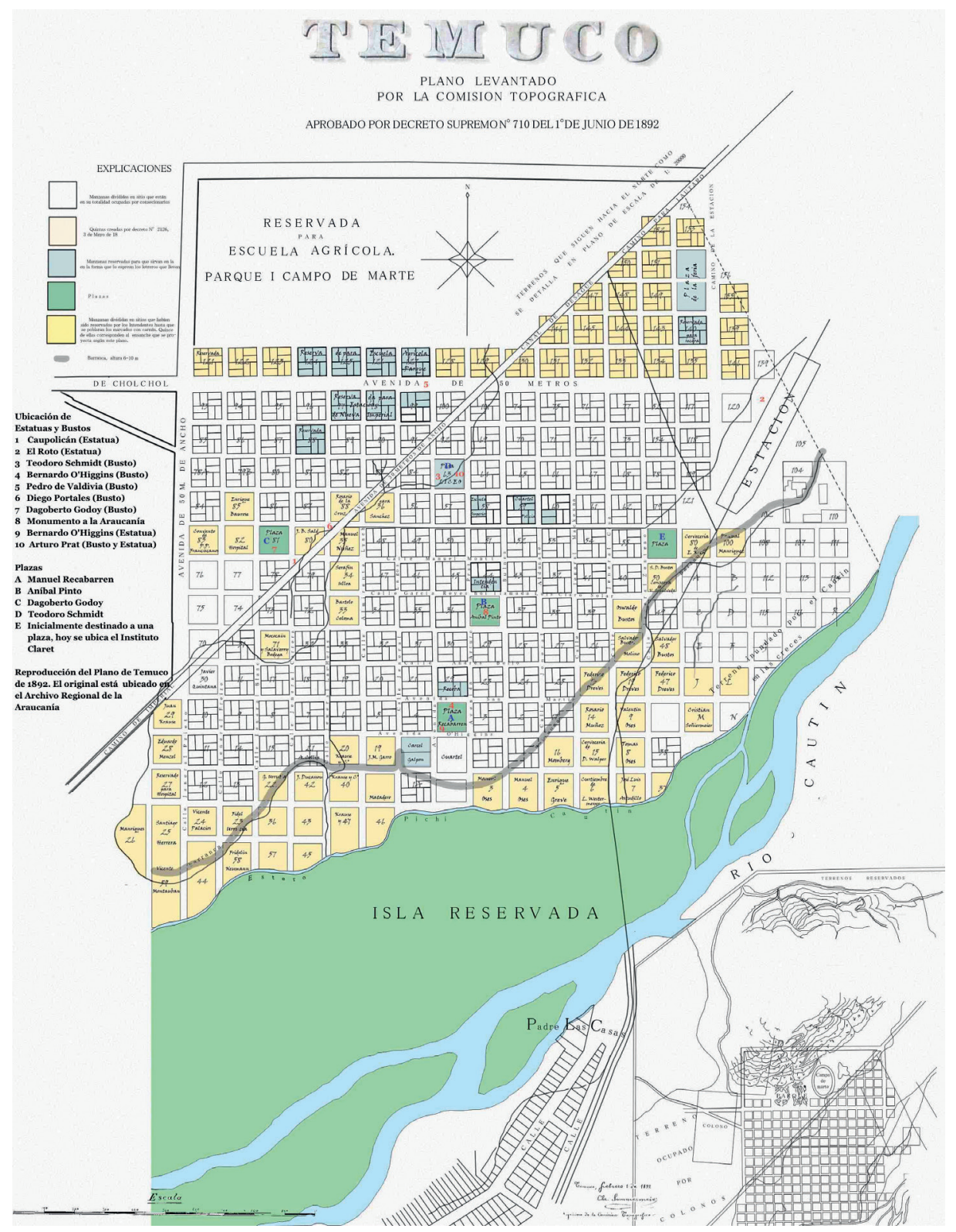

Figura 1

Copia del Plano de Temuco de 1892 . Elaboración propia en base al original que está ubicado en el Archivo Regional de la Araucanía 


\section{TEMUCO, LA \\ SIGNIFICACIÓN DEL ESPACIO PÚBLICO}

Pablo Neruda (1985) afirmó "Temuco es una de esas ciudades pioneras sin pasado, pero con ferreterías". La tarea emprendida por la elite nacional y local fue construir un relato sobre el pasado; la ciudad en sí misma con su arquitectura, calles, plazas y esculturas se constituyó en un espacio para estos fines. Además, es relevante observar el contexto en que se produce la fundación y primeros años de vida de Temuco, momento en que se estampa gran parte de los nombres de sus calles y en este sentido el plano de 1892 constituye una notable evidencia del relato histórico que se buscaba construir ya que, si bien es cierto que el nombre identifica a una calle en particular, una mirada de conjunto nos da la posibilidad de establecer el relato de ellas.

Hasta 1887, Temuco estuvo bajo el control de autoridades militares. Ese año fueron creadas las provincias de Malleco y de Cautín, pasando a tener el régimen político del resto del país, lo que implicó tener autoridades civiles designadas para la administración de las provincias y electas para el gobierno de la ciudad (Flores, 2019). En los primeros años los vecinos habían bautizado las calles arbitrariamente con base en hechos o circunstancias locales, quebrada de los Peumos, calle del Canal, calle de la Lora, Los Tres Robles, la Vega Larga, etc., Schmidt observó la necesidad de asignarle nombres oficiales proponiendo, al Intendente, los de aquellos políticos y militares importantes en la Campaña de Ocupación de la Araucanía (Arellano, 1931). La sugerencia no fue acogida como se observa en el plano de 1892, imponiéndose los militares partícipes en la Independencia, la Guerra contra la Confederación Perú-Boliviana y la Guerra del Pacífico. De esta manera se plasmaron los nombres de General Prieto, General Freire, General Blanco, General Carrera, General Las Heras, Almirante Lynch, General Lagos, Arturo Prat, General Bulnes, General Aldunate, General Mackenna, General Cruz, General Zenteno, O `Higgins y San Martín. El mundo político estaba representado por Antonio Varas, Luis Claro Solar, Manuel Montt y Diego Portales. En 1897, el Consejo Municipal acordó denominar José Manuel Balmaceda a la avenida de 50 metros, -conocida popularmente como "la calle Ancha"-, y con el nombre de Caupolicán a la avenida que la cruzaba en diagonal; Manuel Rodríguez a la primera calle al norte de Portales, Lautaro a la segunda y Miraflores a la tercera (La Frontera, abril 27 de 1897). Así, las calles de Temuco contribuyeron en la construcción de una memoria histórica del estado-nación chileno del siglo XIX, donde Caupolicán y Lautaro aludían a la presencia indígena en tiempos de la Conquista.

En su estudio sobre la escultura pública en Santiago de Chile Liisa Voionmaa (2005) sostiene que en la nación moderna los monumentos conmemorativos, la emblemática y la numismática juegan un rol fundamental en su construcción simbólica. Agrega que, si bien la historia política de una nación está conformada por ideas, son las "imágenes y los símbolos que la expresan" las que constituyen la 
1 De estas plazas dos mantienen el nombre dado en los primeros años; Recabarren, ubicada frente al Regimiento Tucapel, lugar donde se fundó el fuerte que dio origen a Temuco. La segunda es la plaza Aníbal Pinto. Por su parte, la plaza León Gallo, a partir de 1965, pasó a denominarse Dagoberto Godoy, en homenaje al primer aviador chileno que cruzó la cordillera de los Andes en 1918. También conocida como plaza del Hospital, por estar ubicada frente a dicha institución. En la manzana destinada "para Liceo", según el plano de 1892, se conformó una nueva plaza, denominada inicialmente "del Manzano"; más tarde tomó el nombre de Brasil hasta 1942 aproximadamente, cuando fue cambiado por el de Teodoro Schmidt y desde hace unos años se le ha rebautizado popularmente como plaza Lautaro. La expansión urbana de principios del siglo XX dio origen a la Población Dreves, la que contempló una plaza denominada Bismark hacia 1916; 18 de septiembre en 1940 y Dreves en la actualidad.

2 En adelante, ASCMT. visión pública en que un pueblo reconoce su propia identidad. Para Voionmaa, el ciudadano común generalmente registra el "simbolismo oficial" de manera pasiva, no percatándose de toda la carga afectiva que esconden estos obvios signos de identidad colectiva. Allí radicaría la fuerza del símbolo, como la bandera nacional que actúa sobre las personas, aunque éstas lo ignoren, es precisamente la parte afectiva que se concibe como "la base vital del símbolo", la que nutre a lo largo del tiempo el sentimiento de pertenencia. Sin embargo, su efectividad no se manifiesta "con la misma fuerza en la vida cotidiana como en situaciones extraordinarias" (Voionmaa, 2005). De igual modo, no todos los espacios públicos tienen la misma capacidad de maximizar la visibilización de los símbolos (Salgado, 2010).

Para fines del siglo XIX, la plaza era el lugar predilecto donde se instalarían estos símbolos, ésta había "perdido funcionalidad en beneficio de la monumentalidad" (Rojas-Mix, 2002, p.176). En ella se construyen quioscos de música, se diseñan jardines e instalan estatuas. Este es el contexto y el concepto de ciudad presente en la ocupación de la Araucanía, sus plazas no se adscribirán a la funcionalidad colonial sino a la monumentalidad de la modernidad. En I892 se planificaron cuatro plazas para Temuco, más tarde una sería ocupada por el Instituto Claret, las otras: Manuel Recabarren, Aníbal Pinto o de Armas y León Gallo, se fueron desarrollando según el diseño de los planificadores, las ideas y capacidades financieras del municipio. ${ }^{1}$

Estimulados por la celebración del centenario de Chile, en 1909 el Consejo Municipal de Temuco discutió la propuesta del Comité Directivo del Monumento al "Antiguo Arauco" (Actas de Sesiones del Consejo Municipales de Temuco, julio 5 de 1909, p. 43I). ${ }^{2}$ Esta obra, que se ubicaría en la plaza Aníbal Pinto, era "a la memoria de los jenerales que intervinieron en la civilización del territorio indígena" (Ovalle, 1912, p. 97). Según los bocetos, el general Cornelio Saavedra ocupaba un lugar prominente, pero surgió un conflicto, los parientes del general Gregorio Urrutia sostenían que éste debía ocupar el sitio principal debido a sus valerosas acciones por la ocupación del territorio. Otra iniciativa patrocinada por la Sociedad Caupolicán Defensora de la Araucanía, ${ }^{3}$ pedía la aprobación de la municipalidad "al acuerdo del Comité de Fiestas Patrias para colocar el monumento de la "Raza Araucana' en la Plaza Aníbal Pinto" (ASCMT, septiembre I de 1910, p. 12). Ambas iniciativas no llegaron a materializarse; no obstante, ellas dan cuenta de la voluntad de diversas fuerzas por intervenir en el relato histórico de la ciudad. 16 años más tarde, se retoma la idea de un "Monumento a la Araucanía", incluso se habrían pagado algunos dineros al escultor Virginio Arias a cuenta de dicha obra (ASCMT, agosto 28 de 1926, p. 44). Pero poco más se avanzó; luego estalló la crisis económica de 1929 y las fiestas del cincuentenario de la ciudad estuvieron marcadas por la austeridad del momento. 
3 Fue la primera y una de las organización mapuche más influyentes durante el siglo XX.
Para 1934, la Federación Araucana demandaba a la Sociedad Caupolicán información sobre el "estado de las gestiones para erigir el monumento a Caupolicán" (Foerster, R. y Montecino, S., I988, p. I42), una muestra de la voluntad de las organizaciones mapuche por monumentalizar el pasado heroico a través de la figura de Caupolicán y, por esta vía, ocupar un lugar destacado en el espacio urbano. Cinco años más tarde, el alcalde informaba al Consejo Municipal que Manuel Pereira, de la Academia de Bellas Artes de Santiago, ofrecía a la municipalidad "una reproducción en cemento blanco de la escultura original del 'Caupolicán' que hay en el cerro Santa Lucía". La autoridad agregó que había hecho gestiones y un vecino de Temuco obsequiaría este monumento sin implicar gastos a la Corporación. Para su ubicación proponía "el triángulo de la avenida Caupolicán con calle Montt y calle Carrera" (ASCMT, agosto 28 de 1939, p. 182). El 26 de noviembre de 1939, se inauguraba la estatua y la Corporación Araucana preparó una concentración donde "Venancio Coñuepán y José Cayupi fueron los oradores de un acto al cual asistieron más de 1.000 mapuches" (Foerster, R. y Montecino, S., 1988, p. 128) [figura 2]. Más allá de que el Caupolicán de Nicanor

Figura 2

Inauguración de

la estatua de

Caupolicán en 1939.

Fuente: Foerster,

R. y Montecino, S.

1988 , p. 149

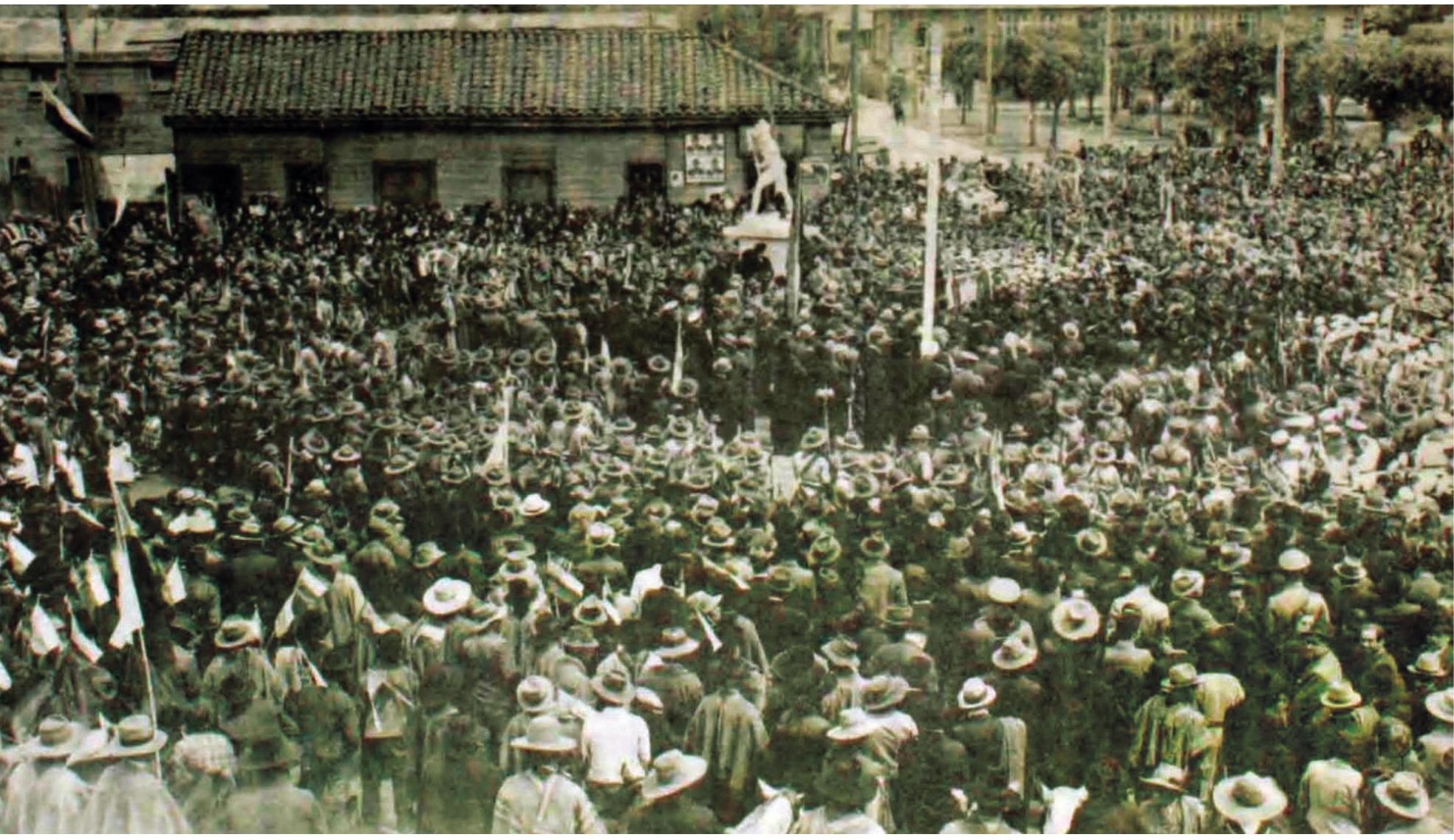


Plaza era una obra destinada a perpetuar la memoria del "último de los mohicanos" (Zamorano, 2011, p. 89), en Temuco fue resignificada por las organizaciones mapuche que habían tenido un rol protagónico en su instalación. Destruida accidentalmente en 1985, pasaron quince años hasta que la figura de Caupolicán se alzara en el mismo lugar. Esta vez las estrofas de Alonso de Ercilla inspiraron al escultor regional José Troncoso para crear un Caupolicán con el tronco de un árbol al hombro. Financiado por Fondart y contando con el apoyo del Museo Regional de La Araucanía y de la Corporación Nacional de Desarrollo Indígena, fue inaugurada el 5 de diciembre de 2000. (El Diario Austral, diciembre 6 de 2000).

En 1940 fue aprobada la adquisición de la estatua al Roto Chileno y su instalación en la plazoleta frente a la Estación de Ferrocarriles, era una copia de la existente en la plaza Yungay de Santiago (ASCMT, septiembre 23 de 1940, p. 95-96). Sin embargo, para 1950 la plaza principal aún no contaba con un monumento y se aproximaba su 70 aniversario. En este marco el Consejo discutió, en varias sesiones, la adquisición, ubicación y sentido de las estatuas en la ciudad. Todo se inició con la materialización de un compromiso contraído el año anterior, en orden a honrar a Teodoro Schmidt por medio de un monumento que se ubicaría en la plaza que lleva su nombre (ASCMT, abril 24 de 1950, p. 4). En la sesión se recordó que el año anterior se había iniciado una colecta sin éxito para adquirir un busto a Bernardo O'Higgins. Se criticaba que "se trata de una simple copia que se pretende vender a todas las ciudades del país. Se ha pensado que es conveniente adquirir una obra de mayor mérito artístico y no un blook (sic) de bronce vendido 'al por mayor' " (ASCMT, abril 24 de 1950, p. 4). Además, se abordó el tema de su ubicación: algunos propusieron la plaza Aníbal Pinto, otros se opusieron aludiendo que en ella se requeriría una obra "de mayor mérito artístico". En esta misma sesión se señaló que existía depositado un dinero para levantar un monumento al Capitán Daniel Rebolledo. (ASCMT, abril 24 de 1950, p. 5).4

La sesión del 24 de julio fue particularmente interesante respecto de la ubicación de los monumentos de la ciudad, ya fuere de aquellos que estaban en debate y los que en el futuro se adquiriesen. Se inició con la cuenta de la Comisión de Ornato, Paseos Públicos y Urbanización, la que proponía que el busto de O'Higgins fuera levantado en la plaza Recabarren, el de Teodoro Schmidt en la plaza que lleva su nombre, reservar la plaza Pinto para el monumento a la Araucanía y que los nuevos monumentos que se erigieran, fuesen ubicados en la avenida Balmaceda, pensada como la principal vía de Temuco (ASCMT, julio 24 de 1950, p. s/n). Luego se dio la palabra y el debate giró en torno a la ubicación del busto a O'Higgins. Algunos de los vocales señalaron que el Intendente de Cautín y el Comandante del Regimiento Tucapel, siguiendo las indicaciones dadas por el Ministerio de Defensa, solicitaban que dicho busto fuera ubicado en la plaza Anibal Pinto, aspecto que compartía el Alcalde. Sin embargo, varios de los vocales mostraron
4 Capitán Daniel Rebolledo fue un militar de ejército que participó activamente en la Guerra del Pacífico, destacando por su temeraria acción de colocar la bandera chilena en la cima del Morro So lar. Falleció en Temuco el 20 de enero de 1908. En la actualidad la Escuela de Suboficiales del Ejército lleva su nombre. 
5 Su ubicación definitiva fue la plaza Recabarren. 6 La placa en el pedestal dice "Homenaje de la Colonia Española, Don Pedro de Valdivia en el IV centenario, Temuco 25-XII-1953". su oposición sosteniendo que no podía ser ubicado en dicha plaza, porque el busto no tenía valor artístico. Además, que "las armas" eran solo un aspecto de la sociedad y el municipio debía velar por el conjunto de ella. Argumentaron que eran ellos quienes tenían el derecho de decidir su ubicación, a pesar de las presiones existentes. Este debate ponía en tensión fuerzas marcadas por el militarismo del pasado y otras de carácter civil que miraban la ciudad del futuro. El pasado y presente militar constituía un sello que había marcado y marcaba el diseño urbano, su arquitectura y los monumentos que lo significaban. Esto estaba presente en la discusión sobre la ubicación del busto de O'Higgins, más allá del valor artístico, lo que le interesaba al Ejército era estar en el centro de la vida y memoria temuquense y no ser desplazado a un lugar secundario.

Al parecer los vientos que soplaban hacia mediados del siglo $X X$ no fueron propicios para la postura del Ejército, a pesar que el busto fue instalado en la plaza Pinto, "provisoriamente", en el marco de la celebración de la "Semana de O'Higgins" (ASCMT, agosto I4 de 1950, p. 4). ${ }^{5}$ La idea del municipio era mejorar el aspecto de la ciudad y para ese efecto acordó adquirir cuatro esculturas de cemento ofrecidas por el Museo de Bellas Artes (ASCMT, agosto 14 de 1950, p. 4). Esta oferta del Museo se enmarcaba en el programa de difusión cultural que estaba desarrollando, para ese efecto "El Eco", "El Jugador de Chueca" y "El Niño de la Fuente" fueron seleccionadas (ASCMT, septiembre 25 de 1950, p. 4). En el ánimo de mejorar la imagen de la Avenida Balmaceda, se aprobó la construcción de la "Cancha de Patinaje" (ASCMT, noviembre 13 de 1950, p. 8-9) y la instalación de un "espejo de agua", obras que serían inauguradas, junto al monumento a Teodoro Schmidt [figura 3], durante los festejos del aniversario número 70 de la ciudad (ASCMT, diciembre 28 de 1950, p. 3). Dos años más tarde, se instaló el busto de Pedro de Valdivia, en la intersección de las calles Balmaceda y Prat. $^{6}$

Durante un par de décadas, la Plaza de Armas tuvo como ornamento central una pileta de agua y dos leones. Pasada la crisis económica de los '80 y a seis años del centenario de Temuco, el municipio encargó un Monumento a la Araucanía, la obra fue una creación conjunta de Guillermo Merino y José Troncoso, inaugurándose el I de junio de 1990. En él, cinco son los personajes representados: el español de los tiempos de la Conquista es Ercilla, en su mano izquierda tiene un pergamino enrollado, trae la escritura; el chileno, es el soldado de la "pacificación"; el mapuche simbolizado en Caupolicán en la versión de un "valiente guerrero"; por su parte una machi, tal vez algo desorientada, efectúa una rogativa en dirección sur; el colono extranjero sembrando "al voleo" es el único que trabaja. En este sentido el monumento constituye una síntesis de nuestra memoria pública nacional-regional, reúne los estereotipos que, en la época, se compartían sobre el pasado [figura 4]. Posiblemente la obra no fue lo que imaginaron en 1910 quienes proponían instalar allí a los generales de la ocupación o 

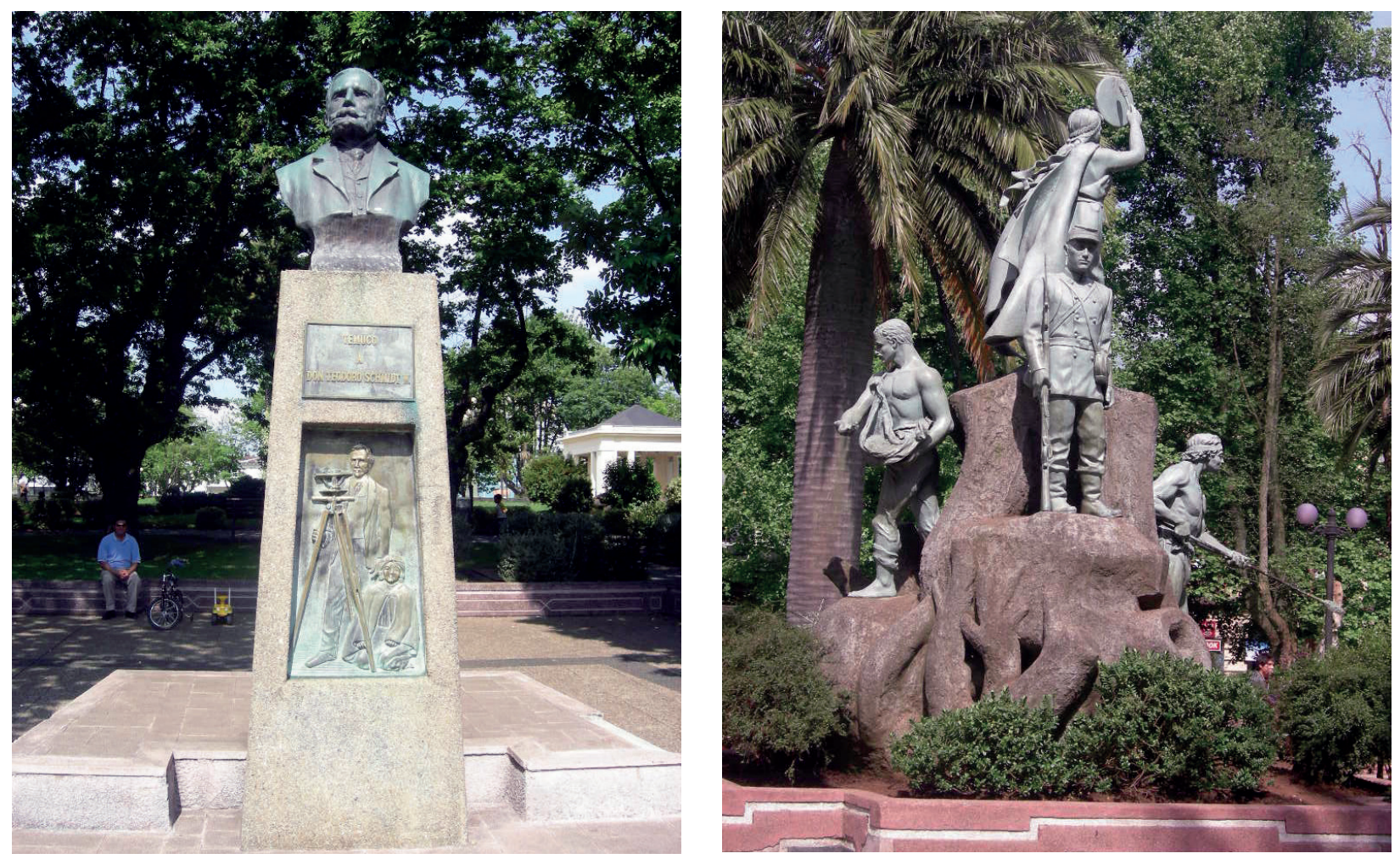

Figura 3

Busto de Teodoro Schmitd ubicado en la plaza homónima.

Es obra de la escultora Blanca Merino y se inauguro en febrero de 1951. Fotografía: Jaime Flores Chávez

Figura 4

Monumento a la Araucanía ubicado en la plaza principal de la ciudad, de la ciudad,

denominada plaza de Armas. de Armas. Es obra de José Troncoso y fue inaugurado en junio de 1990 .

Fotografía: Jaime Flores Chávez la "Raza Araucana". Pasado 80 años, la historia y la memoria "oficial" habían ido construyendo esta imagen del pasado. Por otro lado, la monumentalidad y sentido artístico (es una pieza de gran formato y única) había recogido las voces del Consejo de 1950, pero no su mirada al futuro frente a las antiguas y nuevas voces que se levantaban con la llegada de la democracia. Las sesiones municipales de fines de la dictadura ¿habrán recogido la voz de los mapuches, de las mujeres, de los sectores populares u otras? El resultado muestra que la presencia militar del momento, a diferencia de 1950, se había impuesto.

En la última década dos nuevos monumentos se han instalado en la ciudad financiados por la Universidad Autónoma de Chile.A propósito de la celebración del bicentenario de Chile, donó una estatua de Bernardo O'Higgins la que fue ubicada en la plaza Recabarren y el 20 I 5, con ocasión del 25 aniversario de su fundación, la estatua de Arturo Prat que reemplazó al busto del prócer en la Plaza Teodoro Schmidt. En su inauguración, el rector de dicha universidad señaló "Nosotros creemos que los monumentos simbolizan mucho, simbolizan cultura, son ejemplos a seguir, en definitiva, embellecen la ciudad y esperamos a futuro poder contribuir con otros monumentos a la ciudad de Temuco." Por su parte el alcalde agradeció la donación, manifestando que esta escultura "permitirá enaltecer la imagen de Arturo Prat y que los ojos de los temuquenses y visitantes reconozcan su valor, arrojo y espíritu patrio". (Diario Tiempo2I, mayo 20 de 2015) 


\section{EL ESTALLIDO SOCIAL, LA INTENSIFICACIÓN DE LA RESIGNIFICACIÓN}

El estallido social desencadenado a partir del 18 de octubre de 2019 tuvo, entre sus expresiones más visibles, la ocupación de espacios públicos como calles, avenidas y plazas. También fue profusamente registrado y debatido el "ataque" a los monumentos que, algunos, han asociado a una rebelión contra la historia o cierto tipo de historia. Nuestra estrategia de ubicarlos en perspectiva de larga duración nos conduce por los caminos de la historia y la memoria, del recuerdo y del olvido. Junto con recurrir a los clásicos e importantes trabajos de Pierre Nora sobre Los lugares de la memoria, Maurice Halbwachs que aborda la "memoria colectiva" y Jan y Aleida Assmann respecto de la "memoria cultural", creemos que la idea de "espacios de conmemoración" pudiera ayudar a este propósito.

Para Astrid Erll la memoria cultural es la interacción del presente y el pasado en contextos socio-culturales (Seydel, 2014, p. 205). Ello nos conduce al término de "culturas de rememoración" lo que permite enfatizar la "heterogeneidad y pluralidad de versiones sobre el pasado que conviven en el espacio de un Estado-nación" (Seydel, 2014, p. 206). Este sería un concepto más adecuado para sociedades "postcanónicas" y espacios de mayor tamaño. Estas colectividades de memoria conformarían un espacio de memoria al interior del Estado-nación, pudiendo configurarse estos "espacios de conmemoración" en los niveles nacional e internacional. Seydel sostiene que:

\footnotetext{
"al interior de un Estado-nación compiten diversas memorias por convertirse en la hegemónica, por lo que el estado es una especie de campo de fuerzas en que se negocian e imponen diversas versiones acerca del pasado ... Este enfoque parece particularmente sugerente en países multiétnicos con un pasado fragmentado que es el producto de las constelaciones asimétricas de poder ... En los contextos postcoloniales existen prácticas de rememoración híbridas y, en las últimas décadas, se han puesto en circulación cada vez más representaciones contestatarias acerca del pasado" (Seydel, 2014, p. 207).
}

Además, hoy existen dispositivos que permiten la articulación de formas crecientes de versiones del pasado, en que se manifiestan latencias de la memoria que antes no podían alcanzar a un número mayor de personas, por medio del cine independiente, el Internet, las performances y escratches de diversos grupos y movimientos sociales (Seydel, 2014).

Temuco no estuvo ajena al estallido social. Más aún, al parecer aquí fue donde se inició el derribo de bustos y estatuas el 29 de octubre, en el marco de la "Marcha Mapuche". Los nombres de las calles no fue el foco de la protesta, como sí lo fueron otros símbolos urbanos 


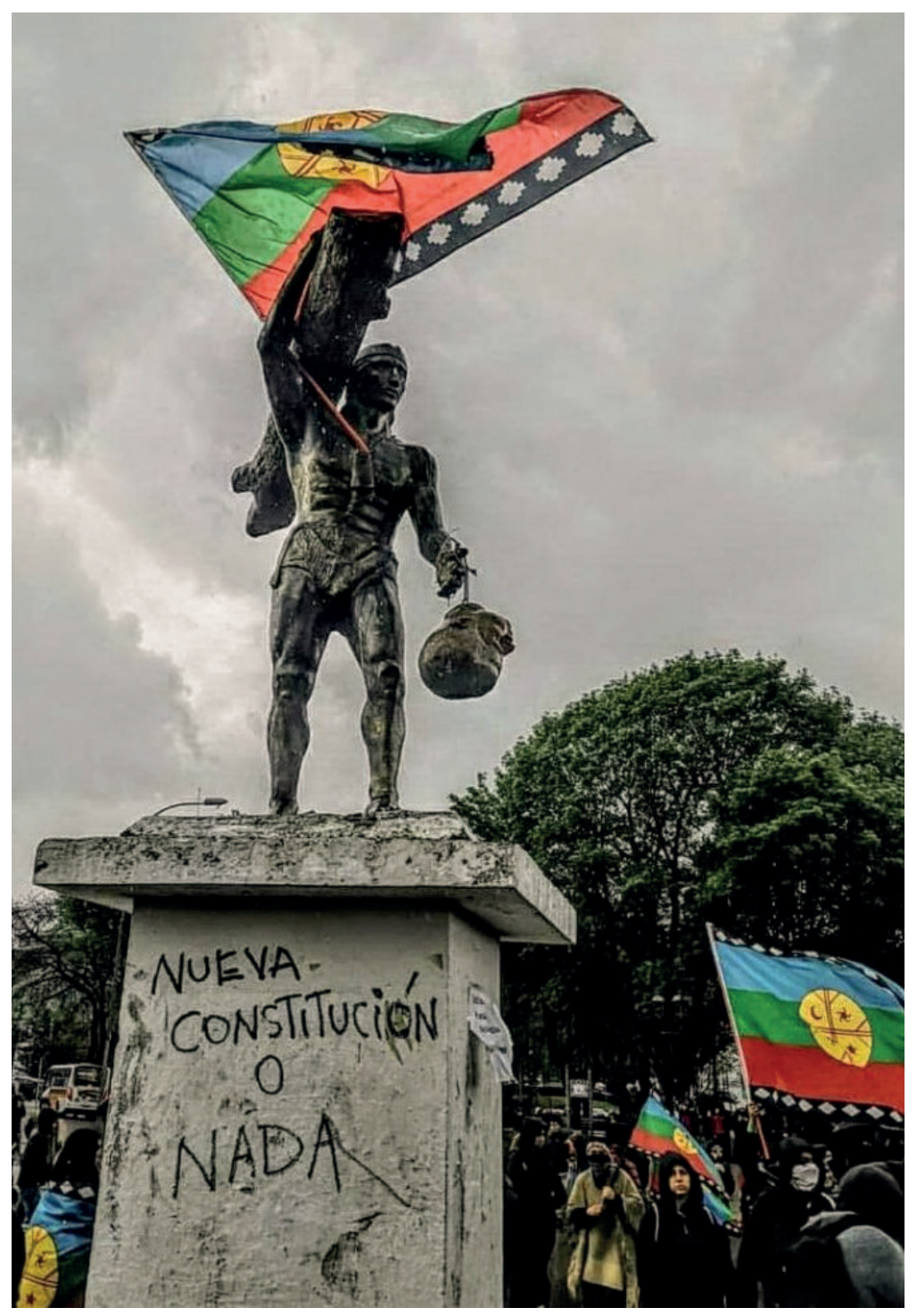

Figura 5

Estatua de Caupolicán, la cabeza de Dagoberto Godoy atada por una cuerda cuelga de su mano. Fuente: https:// www.eldesconcierto.cl/2019/10/29/ video-manifestantes-decapi-

tan-busto-de-militar-y-ponen-su-catar-y-ponen-su-ca-
beza-en-las-manos-de-estatua-de-caupolican/
7 En un primer momento algunos medios informaron que era la cabeza de Pedro de Valdivia, lo que hacia la escena más dramática, impactante y simbólica. como la reivindicación del nombre de plazas y la destrucción de monumentos. Tal vez la imagen que quedó en la retina de todos fue la cabeza de Dagoberto Godoy pintada de rojo colgando de una cuerda atada a la mano de Caupolicán 7 [figura 5]. Aquel día, esta escena y el derribamiento de los bustos de Pedro de Valdivia y de Diego Portales se transmitieron en directo a todo el país. Estas imágenes fueron difundidas por televisión, radio y prensa escrita, además de propagarse por las redes sociales.

El I 4 de noviembre, El Diario Austral de Temuco informaba que, durante la marcha por la conmemoración de la "muerte de Camilo Catrillanca, encapuchados" derribaron la estatua de Arturo Prat. 


\section{Figura 6}

Luego de ser derribados la estatua de Arturo Prat y el

busto de Teodoro

Schmidt fueron uti-

lizados como parte

de las barricadas

que se levantaron en

el centro de Temuco.

Fuente: https://

www. soychile.

cl/Temuco/Socie-

da019/11/14/625093/

Manifestantes-derri-

Manifestantes-derri-

baron-estatua-de-Ar

aspx
Aunque las miradas se concentraron en Prat, al otro costado de la plaza el busto de Teodoro Schmidt también había sido derribado, como lo muestran las fotografías que acompañaban la noticia [figura 6]. Dos días más tarde, la prensa difundía un comunicado de la Armada de Chile en que "agradece enormemente los esfuerzos de Carabineros por rescatar, limpiar y restaurar la estatua de Arturo Prat Chacón", precisando que la estatua había sido remitida a la Gobernación Marítima con asiento en Valdivia. (El Diario Austral, noviembre 16 de 2019).

El 19 de noviembre, en un acto convocado por la Asamblea Popular Plurinacional de Temuco, se efectuó el renombramiento de manera simbólica de la plaza Teodoro Schmidt a Plaza Leftxaru (Lautaro). En la oportunidad, Ana Llao señaló que "hoy más que nunca (existe) la necesidad de recuperar los espacios, considerando que estamos en territorio mapuche"; la nota de prensa advertía la "importancia simbólica del despojo de figuras colonizadoras, genocidas y asesinas; bajo el manto de figuras históricas que instauraron las lógicas de impunidad que hoy se replican sin juicio y castigo para
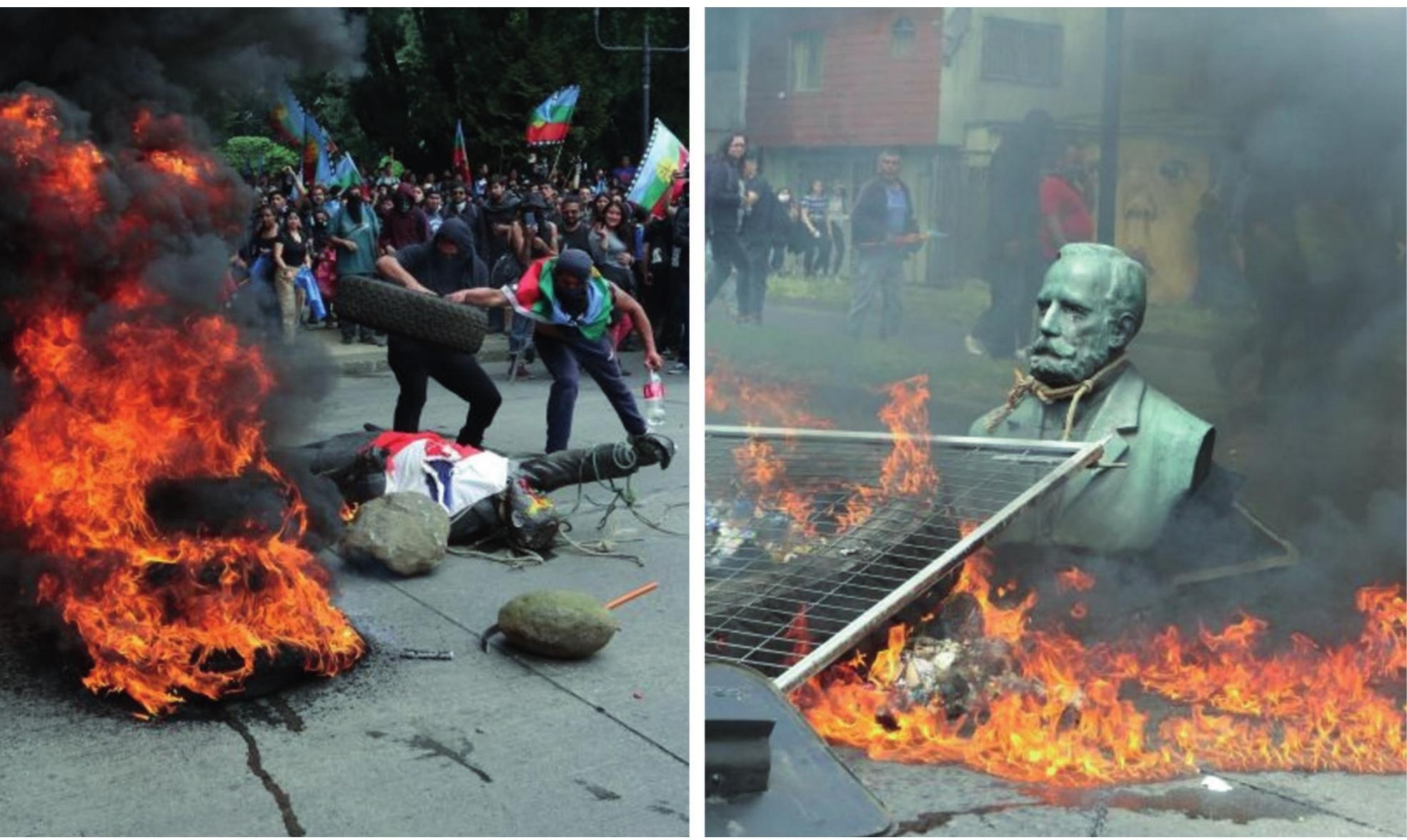


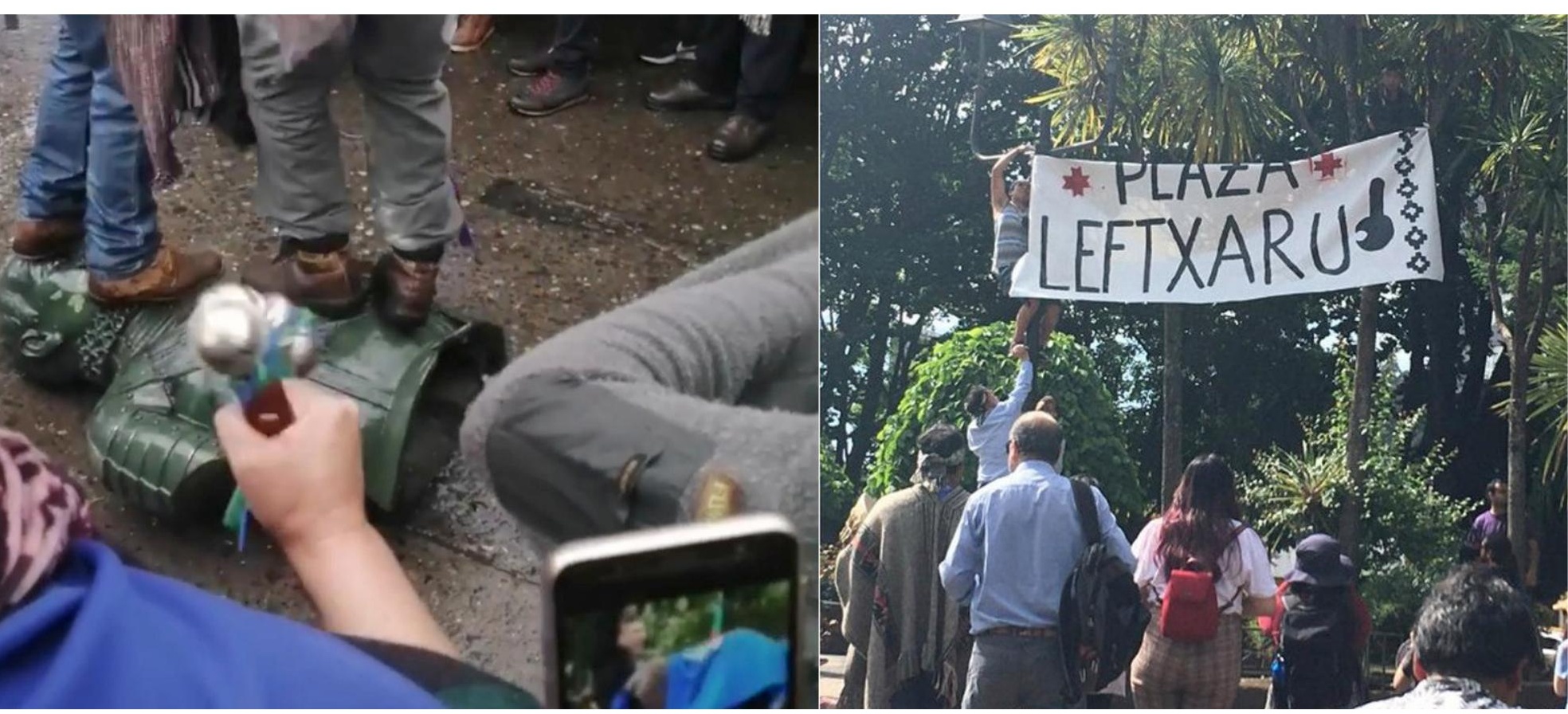

los culpables" recurriendo a estas "reivindicaciones simbólicas como señal de desvalidez a estas figuras patrióticas." La dirigente mapuche afirmó que era "tiempo de poner estatuas de nuestros mártires ... (y) renombrar varios lugares de la región." Luego, hizo uso de la palabra Marcelo Catrillanca, padre de Camilo Catrillanca, planteando que no era la idea aceptar las propuestas del gobierno y "que si bien el lienzo es simbólico es importante la participación del pueblo mapuche y más sectores de la sociedad" [figura 7]. reconociendo como un actor clave del estallido a la juventud. (La Izquierda Diario, noviembre 22 de 2019).

"Recordar y olvidar son las dos caras -o bien, son dos procesos diferentes- de un mismo fenómeno: la memoria" (Erll, 2016, p. 10), pero de alguna manera también lo son de la historia, en el entendido que la construcción de ésta, su investigación y escritura, implica una selección de lo que queremos historiar y por ende un "intencionado olvido" de aquello que creemos no es relevante o que resulta peligroso narrar. Procesos de esta naturaleza se hacen más evidentes en territorios como la Araucanía en donde "memoria comunicativa", en lenguaje de Jan y Aleida Assmann, está activa y el de "memoria cultural" se hace presente. Las usurpaciones de tierra es un saber compartido generacionalmente, al tiempo que la estatua de Caupolicán o el busto de Pedro de Valdivia constituyen objetos e imágenes "disponibles para volver a ser usados operan(do) como registros y catalizadores que refundan permanentemente la memoria grupal."
Figura 7

Dos fotografías dan cuenta de la reivindicación mapuche $y$ el estallido social. La primera, busto de Pedro de valdivia pisoteado por manifestantes. La kaskawilla y parte de la escena. parte de la escena.
Fuente: https://www. youtube.com/watch? $\mathrm{v}=1 \mathrm{wbJ} 4 \mathrm{bi-eg} 8 \mathrm{~L}$.

La segunda fotografía, instalación de un lienzo con el que, simbólicamente, se cambió el nombre de plaza Teodoro Schmidt por plaza Leftxaru. Fuente: http://www. laizquierdadiario. cl/Cambio-de-nombre-a-Plaza-Lefxaru-Lautaro-ex-plaru-Lautaro-ex-pladt-una-deuda-historica 
8 También existe la wüñelfe, la bandera azul con una estrella de ocho puntas.

9 Nos referimos a la fotografía de Susana Hidalgo que publicó en Instagram el 25 de octubre de 2019 y se viralizó rápidamente.
(Dolff, 2010, p. 32). Es posible que sean estas "culturas de rememoración", en lenguaje de Erll, lo que ha estado y está presente en las calles de Temuco, en las marchas mapuche del pasado y del presente, esta "competencia" de diversas memorias al interior del Estado-nación es lo que ha ocurrido desde la misma fundación de la ciudad, expresada en el ataque al fuerte Temuco en 1881; la denominación de las calles Caupolicán y Lautaro en 1897; la propuesta en 1910 de la Sociedad Caupolicán Defensora de la Araucanía de levantar un monumento a la "Raza Araucana" en la plaza principal; la instalación del Monumento a Caupolicán en 1939 y vuelto a construir, en una nueva versión, el año 2000; la demanda de renombrar la plaza Teodoro Schmidt por Lautaro, uno de cuyos actos simbólicos más recientes se efectuó hace unos meses. Todos son una muestra de la "adaptación", "negociación" y "resistencia" de otras versiones del pasado, en el largo plazo.

En esta disputa por la memoria, por situar símbolos identitarios que "conmemoren" para sí y para otros, el estallido social fue una coyuntura propicia para la instalación de la wenufoye (bandera mapuche) en la iconografía nacional. ${ }^{8}$ Fue el corolario como signo de identificación de la nación mapuche a nivel nacional e internacional. Creada en 1992, su estreno se produjo aquel año en el contexto de una marcha mapuche, fuertemente reprimida por carabineros "En un momento de calma, un Werken, sobre la carrocería de una camioneta estacionada ... alza con sus manos la bandera oficial" (Weken, 2012). Con el paso de los años, esta bandera se fue popularizando. Cada vez fueron más las que flameaban en las marchas indígenas efectuadas en distintas ciudades de la Araucanía y del país. Para el estallido social su uso traspasó las manos y las demandas mapuche, constituyéndose en unos de los iconos distintivos de las diversas movilizaciones a nivel nacional. En uno de esos eventos, se arriaron las banderas chilenas que flameaban frente a la Municipalidad de Temuco y en su reemplazo se izó la bandera mapuche. Pero sin duda una de las imágenes más simbólicas del estallido captó, en la ciudad de Santiago, a una multitud de persona sobre la estatua del General Baquedano y en la cima, flameando, la wenufoye ¿era el "pueblo de Chile" resignificando la bandera mapuche?. 


\section{CONCLUSIONES}

Figura 8

Avenida Caupolicán

de Temuco, en primer

plano los busto de

Diego Portales y Da-

goberto Godoy sin su

cabeza, la que había sido colgada del

brazo de Caupolicán.

octubre 29 de 2019

Fuente: https://

temucotelevision.

$\mathrm{cl} / \mathrm{web} / 2019 / 10 / 29 /$

temuco-marcha-ma-

puche-se-desarro-

lla-con-danos-al-me-

nos-a-dos-monumen-

tos/
Los días 29 de octubre, 14 y 19 de noviembre de 2019, el centro de Temuco fue el escenario de una serie de manifestaciones que canalizaban la demanda mapuche: la de la historia y el reconocimiento, esta vez concentradas en tiempo y lugar. Como lo habían hecho desde principios del siglo XX, marchaban por las calles haciendo sonar sus instrumentos, arengando en mapudungun $y$ portando pancartas en dicha lengua. Los medios de comunicación informaron por los canales formales y, el celular de los manifestantes, registró fotografías y videos que se difundieron por las redes sociales [figura 8].

139 años antes, se había fundado Temuco, expresión y contenedor del discurso hegemónico del Estado-nación chileno, lo cual puede ser observado en el nombre de sus calles, plazas y los monumentos que en ella se fueron instalando; estos últimos es posible clasificarlos en tres grupos: Pedro de Valdivia, Bernardo O'Higgins, Diego Portales y Arturo Prat responden a la idea de panteón nacional. En otro plano, encontramos los bustos de Manuel Recabarren, Teodoro Schmidt y Dagoberto Godoy, más vinculados a la historia de la ciudad, en el entendido que el

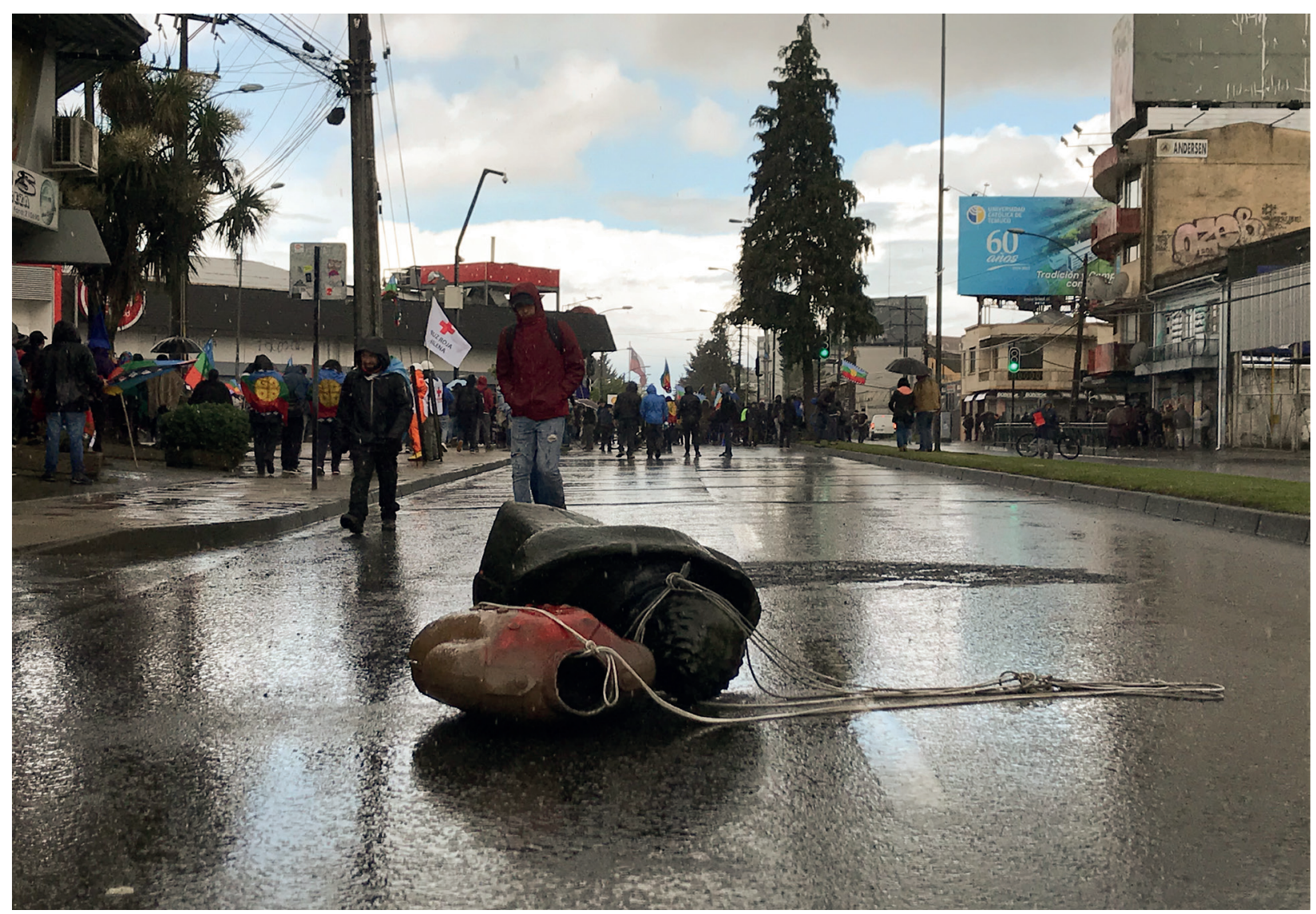

AS / Vol. 38. No58 / JULIO 2020 // ISSN impresa 07 16-2677 / ISSN digital 0719-6466 
primero fue quien la fundó; el segundo quien hizo el trazado de sus calles y luego se avecindó en ella hasta su muerte; y el tercero, nacido en la ciudad y transformado en "héroe nacional", al ser el primero en cruzar en avión la cordillera de los Andes. Por su parte, la estatua "helenizante" de El Roto (Ivelic, 200 I) reivindica al pueblo victorioso en la Guerra contra la Confederación y la Guerra del Pacífico, y en el caso de las estatuas de Caupolicán, más allá de la estética en sus dos versiones, fue posible constatar su resignificación y apropiación por las organizaciones mapuches de 1939, así como en las movilizaciones que traspasaron lo mapuche de octubre 20 I9. Su posición estratégica en el radio urbano de Temuco la hace formar parte de la "zona cero". El Monumento a la Araucanía que se impone en el centro de la Plaza de Armas se constituye en una suerte de síntesis de la memoria pública nacional-regional.

Finalmente, en esta mirada de largo plazo podemos identificar seis momentos en el proceso de significación y resignificación de la ciudad de Temuco expresado en sus monumentos. El primero, a propósito del centenario de Chile, el surgimiento y debate de la idea de un "Monumento a la Araucanía"; el segundo, a inicios del Frente Popular, con la instalación de las estatuas de Caupolicán y El Roto, una suerte de la inclusión de lo alterno en el espacio urbano; el tercero, hacia mediados de siglo $X X$, con el ordenamiento del espacio monumental, identificación y jerarquización de lugares y estatuas. Es el momento en que se instalan los bustos de O'Higgins, Schmidt y Valdivia, y se consolida la idea de reservar la Plaza de Armas al Monumento a la Araucanía; 1981, el año del centenario de la ciudad, se instala el busto de Portales y se da un nuevo impulso al Monumento a la Araucanía que se termina por materializar en 1990; el quinto, 20 I0-15, la reivindicación de los héroes patrios con las estatuas de O'Higgins y Prat; por último, octubre-noviembre de 2019, las protestas contra la historia y la memoria "oficial" a través de la destrucción de algunos monumentos, una señal que muestra la importancia y urgencia del debate sobre la resignificación del espacio urbano acorde a los tiempos pasados, presentes y futuros [figura 9]. 


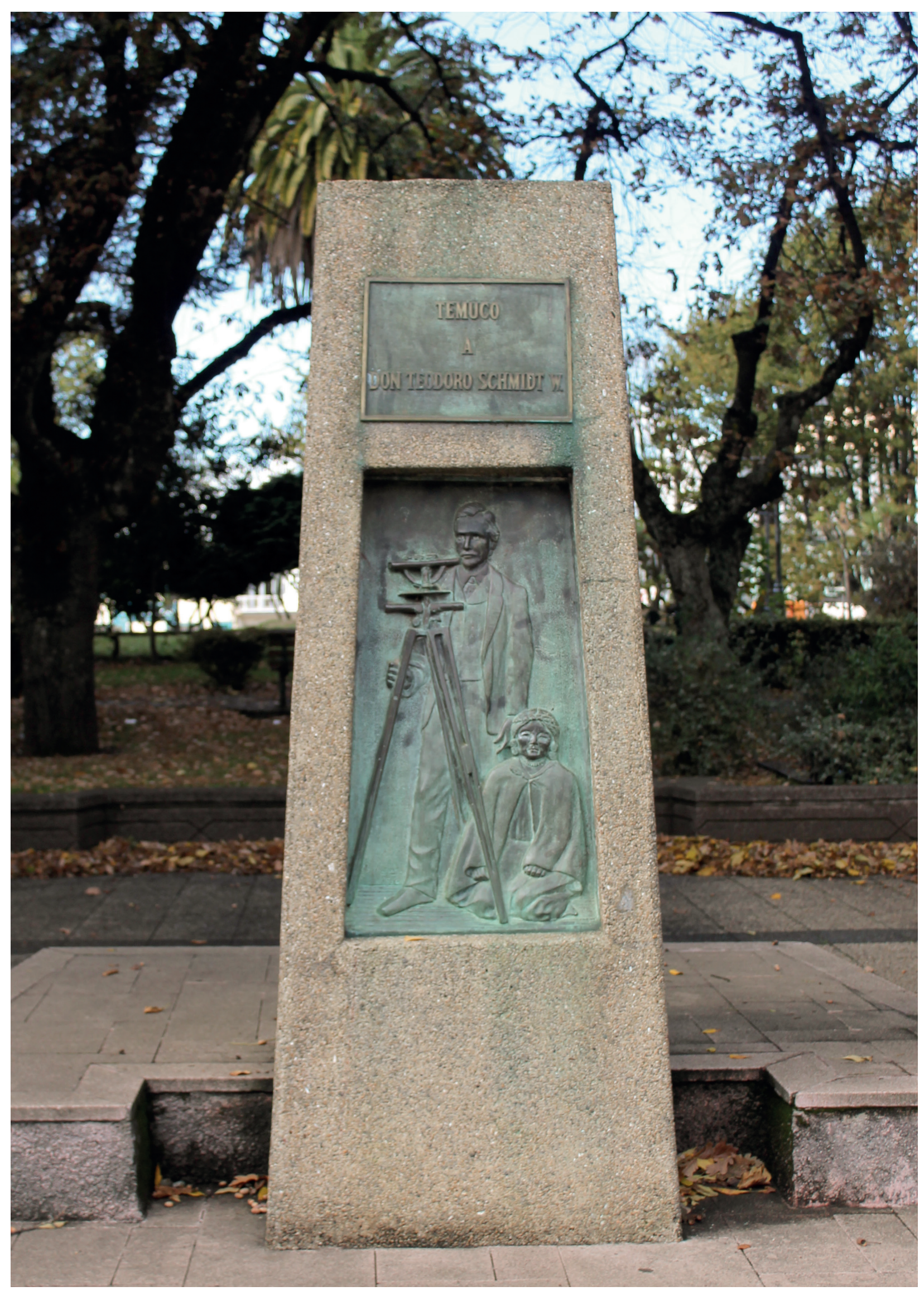




\section{REFERENCIAS BIBLIOGRÁFICAS}

Actas de Sesiones del Consejo Municipales de Temuco (ASCMT) (1909).

Actas de Sesiones del Consejo Municipales de Temuco (ASCMT) (1910).

Actas de Sesiones del Consejo Municipales de Temuco (ASCMT) (1926).

Actas de Sesiones del Consejo Municipales de Temuco (ASCMT) (1939).

Actas de Sesiones del Consejo Municipales de Temuco (ASCMT) (1940).

Actas de Sesiones del Consejo Municipales de Temuco (ASCMT) (1950a), 24 de abril.

Actas de Sesiones del Consejo Municipales de Temuco (ASCMT) (1950b), 24 de julio.

Actas de Sesiones del Consejo Municipales de Temuco (ASCMT) (1950c), 14 de agosto.

Actas de Sesiones del Consejo Municipales de Temuco (ASCMT) (1950d), 25 de septiembre.

Actas de Sesiones del Consejo Municipales de Temuco (ASCMT) (1950e), 13 de noviembre.

Actas de Sesiones del Consejo Municipales de Temuco (ASCMT) (1950f), 28 de diciembre.

ARELLANO, O. (1931). Reseña histórica de Cautín en el cincuentenario de Temuco. Temuco: Imprenta Gutiérrez.

COLOM, F. (ed.) (2016). Forma y política de lo urbano. La ciudad como idea, espacio y representación. Bogotá: Editorial Crítica.

DIARIO TIEMPO21. (2015). Universidad donó estatua de Arturo Prat para la plaza Teodoro Schmidt de Temuco. (mayo 20 de 2015). Recuperado de http://tiempo21 araucania.cl/universidad-dono-estatua-de-arturo-prat-para-plaza-teodoro-schmidt-de-temuco/

DOLFF, G. (2010). "Topografías del recuerdo y colectivos de memoria". En: Birle, P.; Carnovale, V.; Gryglewski, E. y Schindel, E. Memorias urbanas en diálogo: Berlín y Buenos Aires. Buenos Aires: Editorial Obra Completa.

EL DIARIO AUSTRAL. (2000). Caupolicán domina nuevamente su avenida. (diciembre 6 de 2000). Recuperado de http://www.mapuche.info/news01/ austral001206.html

EL DIARIO AUSTRAL. (2019). Manifestantes derribaron estatua de Arturo Prat en Temuco. (noviembre 14 de 2019). Recuperado de https://www. soychile.cl/Temuco/Sociedad/2019/11/14/625093/ Manifestantes -derribaron-estatua-de-Arturo-Prat-en-Temuco.aspx

EL DIARIO AUSTRAL. (2019). Carabineros de Temuco recuperó estatua de Arturo Prat y se la entregó a la Armada. (noviembre 16 de 2019). Recuperado de https:// www.soychile.cl/Temuco/Sociedad/2019/11/16/625368/Carabineros-de-Temuco-recupero-estatua-de-Arturo-Prat-y-se-la-entrego-a-la-Armada.aspx

ERLL, A. (2016). Memoria colectiva y cultura del recuerdo. Estudio introductorio. Colombia: Ediciones Uniandes.

FLORES, J. (2019). "La construcción del Estado chileno en la Araucanía a través de los papeles del Fondo de Intendencia de Cautín, 1887-1914". En: Bajo la Lupa, Subdirección de Investigación, Servicio Nacional del Patrimonio Cultural, Archivo Nacional de Chile. Recuperado de https://www.archivonacional.gob.cl/616/articles-93552_archivo_01.pdf

FOERSTER, R. Y Montecino, S. (1988). Organizaciones, líderes y contiendas mapuches (1900-1970). Santiago: Ediciones CEM.

HIDALGO, S. Fotografía publicada en Instagram el 25 de octubre de 2019. www.instagram.com. 
IVELIC, R. (2001) "Escultura chilena e identidad (1900-1970)". Aisthesis, n 34, pp. 153-170.

LA FRONTERA. (1897). Periódico de Temuco, (abril 27 de 1897).

LA IZQUIERDA DIARIO. (2019). Una deuda histórica: cambio de nombre a Plaza Lefxaru (Lautaro), ex plaza Teodoro Schmidt. (noviembre 22 de 2019). Recuperado de http://www.laizquierdadiario.cl/ Cambio -de- nombre-a-Plaza-Lefxaru-Lautaro-ex-plaza-Teodoro-Smichdt-una-deuda-historica

LA MAÑANA. (1917). Periódico de Temuco. (febrero 24 de 1917).

LEÓN, L. (1981). "Alianzas militares entre los indios araucanos y los grupos indios de las pampas: la rebelión araucana de 1867-1872 en Argentina y Chile". Nueva Historia n 1, pp.3-49.

LLORENTE, M. (2015). La ciudad: huellas en el espacio habitado. Barcelona: Editorial acantilado.

MEMORIA DEL MINISTERIO DE GUERRA. (1882). Memoria del Comandante en Jefe del Ejército del Sur, sobre el último alzamiento de indígenas. Angol, diciembre 23 de 1881. p. 186.

MUMFORD, L. (2012). La ciudad en la historia. Sus orígenes, transformaciones y perspectivas. Logroño: Pepitas de calabazas ed.

NERUDA, P. (1985). Confieso que he vivido. México: Editorial Planeta.

OVALLE, F. (1912). Por el Sur de Chile. Civilización desconocida. Santiago: Imprenta i encuadernación "La llustración".

PINTO, J. (2015). La formación del Estado y la nación, y el pueblo mapuche. De la inclusión a la exclusión. Santiago: Dibam.

ROJAS-MIX, M. (2002). La plaza mayor. San José, Costa Rica: Editorial de la ciudad de Costa Rica.

SAAVEDRA, C. (1870). Documentos Relativos a la Ocupación de Arauco. Santiago: Imprenta de La Libertad.

SALGADO, A. (2010). "Escultura pública e identidad nacional: Chile, 18911932. En: Cid, G. Y San Francisco, A. Nacionalismo e Identidad Nacional en Chile. Siglo XX. Vol 1. Santiago: Centro de Estudio Bicentenario, pp. 159-190.

SEYDEL, Ut. (2014). "La constitución de la memoria cultural", en revista Acta Poética, Vol. 35, n² 2, Julio-diciembre, pp. 187-214.

VOIONMAA, L. (2005). Escultura pública. Del monumento conmemorativo a la escultura urbana. Santiago 1792-2004. Santiago: Ocho Libros Editores, Santiago.

WEKEN, J. (2012). Historia de la creación de la bandera mapuche. Significados de formas y colores. Recuperado de https://www.mapuexpress. org/2015/05/07/historia-de-la-creacion-de-la-bandera-mapuche/

ZAMORANO, P. (2011). "Nicanor Plaza y Francisco Gazitúa: diálogo en torno a El Caupolicán". Aisthesis, n 49, pp. 84-100. 